\title{
The role of endoluminal interventions in the preparation of high-risk patients with super-obesity for bariatric surgery
}

\author{
O. Y. Ioffe, M. S. Kryvopustov, O. P. Stetsenko, T. V. Tarasiuk, Y. P. Tsiura \\ Bohomolets National Medical University, Kyiv
}

\author{
Mykola Kryvopustov: mykola.kryvopustov@gmail.com \\ O. Y. Ioffe, http://orcid.org/0000-0002-1306-7920 \\ M. S. Kryvopustov, http://orcid.org/0000-0003-4978-4873 \\ O.P. Stetsenko, http://orcid.org/0000-0002-2219-653X \\ T.V. Tarasiuk, http://orcid.org/0000-0001-6629-3908 \\ Y.P. Tsiura, http://orcid.org/0000-0001-6651-8564
}

Obesity causes increased morbidity, disability and mortality rates as well as affects the quality of life. Given the known risks to the patient's health, the International Federation for the Surgery of Obesity and Metabolic Disorders pays special attention to the problem of morbid obesity (body mass index $\geq 40 \mathrm{~kg} / \mathrm{m}^{2}$ ), with particular emphasis on super-obesity (body mass index $\geq 50 \mathrm{~kg} / \mathrm{m}^{2}$ ).

Овјестіve is to investigate the role of endoluminal interventions in the preparation of super obese patients with high risk of surgical and anaesthesia-related complications for bariatric surgery.

Materials AND METHODS. From 2011 to 2018, 97 patients with morbid obesity and high risk of surgery and anaesthesia-related complications (ASA PS III-IV) underwent a course of treatment at the clinical setting of the Department of General Surgery No2 of Bohomolets National Medical University. The treatment was carried out in 2 stages. In the main group $(n=60)$, the first stage of treatment included the intragastric balloon placement for a term of 6 months. The control group $(n=37)$ received a six-month conservative therapy. In the second stage of treatment the patients of both groups underwent a surgical procedure for the morbid obesity management.

RESUlts. The outcomes of the first stage of treatment showed that the patients, who underwent the intragastric balloon placement, had statistically significantly $(p<0.001)$ higher mean the percentage of excess weight loss (\% EWL) than the patients who received conservative therapy. In the main group, the average ASA PS score, which is identified as an anaesthetic and surgical risk indicator, decreased from 3.28 (95\% confidence interval (CI) $3.17-3.40)$ to 2.15 (95\% CI 2.06-2.24, p < 0.001), and in the control group - from 3.24 (95\% CI 3.10-3.39) to 3.14 (95\% CI 2.96-3.31, p > 0.05).

Conclusions. The results of the study provide strong evidence that the intragastric balloon placement for a term of 6 months reduces surgical and anaesthetic risks, contributes to the improved function of the cardiovascular and respiratory systems as well as gives a boost to carbohydrate metabolism, and, therefore, can be suggested for the preparation of super obese patients with high risk of surgical and anaesthesia-related complications for bariatric surgery.

\section{KEYWORDS}

morbid obesity, bariatric surgery, type 2 diabetes mellitus.

ARTICLE • Received 2021-10-18 • Received in revised form 2021-10-20

(c) General Surgery, 2021

Obesity is an urgent health problem as its social and health impact is extremely high today. Around $13 \%$ of adults worldwide are suffering from obesity. According to the global health estimates, by 2025 about $20 \%$ of the world population will be diagnosed with obesity [9]. Obesity causes increased morbidity, disability and mortality rates as well as affects the quality of life [7]. Given the known risks to the patient's health, the International Federation for the Surgery of Obesity and Metabolic Disorders (IFSO) pays special attention to the problem of morbid obesity (body mass index (BMI) $\geq 40 \mathrm{~kg} / \mathrm{m}^{2}$ ), with particular emphasis on superobesity (BMI $\left.\geq 50 \mathrm{~kg} / \mathrm{m}^{2}\right)$ [12]. 
The inadequate effectiveness of conservative methods of treatment necessitates the application of bariatric surgery [3, 8]. However, these patients have a high surgical and anaesthetic risk, including in terms of anaesthesia administration. Particularly serious problems result from the complications of pulmonary embolism, which are presented in a 24-year retrospective analysis of bariatric interventions [11]. In general, postoperative mortality in obese patients is 2 times higher than in people with normal body weight [10].

E. J. DeMaria et al. (2007) propose the OSMRS (The Obesity Surgery Mortality Risk Score) scale, which is based on five preoperative variables that increase the risk of morbidity and mortality within 30 days after gastric bypass. They are age $\geq 45$ years, BMI $\geq 50 \mathrm{~kg} / \mathrm{m}^{2}$, hypertension, male gender and pulmonary embolism $[1,5]$.

A multicenter Brazilian study showed that due to the use of IGB for 6 months, patients with obesity lost an average of $26.1 \mathrm{~kg}(3.6-77.0 \mathrm{~kg})$, the average \%EWL was $23.5 \%(3.0-54.0 \%)$, the average BMI decreased by $8.5 \mathrm{~kg} / \mathrm{m}^{2}\left(1.3-24.9 \mathrm{~kg} / \mathrm{m}^{2}\right)$, the clinical picture of comorbid conditions (hypertension, diabetes, sleep apnoea, etc.) improved [13].

A study of the effect of IGB on body weight loss and comorbidity, conducted at the University of Padova (Italy) showed that the use of IGB for $164.4 \pm 39.7$ days (92-240 days) led to a decrease in body weight by $26.4 \pm 10.2 \mathrm{~kg}(5.0-53.0 \mathrm{~kg})$, the average \%EWL was $26.1 \pm 9.3 \%(5.1-55.2 \%)$, the average BMI decreased from $58.4 \pm 6.6 \mathrm{~kg} / \mathrm{m}^{2}$ to $49.3 \pm 6.2 \mathrm{~kg} / \mathrm{m}^{2}$ $(\mathrm{p}<0.001)$, decreased surgical risk [14].

In the analysis of 30 studies involving $4,877 \mathrm{pa}-$ tients, it was shown that the use of IGB BIB led to a decrease in body weight by $4.9-28.5 \mathrm{~kg}$ (average $-17.8 \mathrm{~kg}$ ), and BMI by $4.0-9.0 \mathrm{~kg} / \mathrm{m}^{2}$. In principle, comorbid conditions disappeared or improved in $52-100 \%$ of these patients [15].

Thus, the presence of super-obesity is a direct indication for bariatric surgery. However, it is necessary to use effective strategies to reduce surgical risk.

Овјестіve is to investigate the role of endoluminal interventions in the preparation of super obese patients with high risk of surgical and anaesthesiarelated complications for bariatric surgery.

\section{Materials and methods}

From 2011 to 201897 patients with super-obesity and high risk of surgery and anaesthesia-related complications (ASA PS III-IV) underwent a course of treatment at the clinical setting of the Department of General Surgery No2 of Bohomolets National Medical University (Table 1). The study included 45 (46.4\%) men and 52 (53.6\%) women.

The treatment was carried out in 2 stages. In the main group $(n=60)$, the first stage of treatment included the intragastric balloon placement for a term of 6 months. The control group $(n=37)$ received a six-month conservative therapy focused on dietary changes, physical activity and behavioural therapy. In the second stage of treatment the patients of both groups underwent surgical procedure for the morbid obesity management [1]. The main and control groups did not have a statistically significant difference $(\mathrm{p}>0.05)$ in gender, age and clinical variables; therefore, they were comparable. The course of the study included 6 months of the

Table 1. Anthropometric variables in patients with super-obesity in the first stage of treatment

\begin{tabular}{|c|c|c|c|c|c|c|c|}
\hline \multirow{2}{*}{ Variables } & \multicolumn{3}{|c|}{ Main group $(n=60)$} & \multicolumn{3}{|c|}{ Control group $(n=37)$} & \multirow{2}{*}{$\mathrm{p}^{*}$} \\
\hline & Before treatment & After treatment & $\mathbf{p}$ & Before treatment & After treatment & $\mathbf{p}$ & \\
\hline Body weight, kg & $\begin{array}{l}192.47 \pm 24.85 \\
(132-231)\end{array}$ & $\begin{array}{l}163.55 \pm 19.75 \\
(115-185)\end{array}$ & $<0.001^{\#}$ & $\begin{array}{c}190.27 \pm 23.37 \\
(128-227)\end{array}$ & $\begin{array}{l}186.97 \pm 19.94 \\
(120-215)\end{array}$ & 0.051 & $<0.001^{\# \#}$ \\
\hline BMI, $\mathrm{kg} / \mathrm{m}^{2}$ & $\begin{array}{c}68.30 \pm 7.38 \\
(53.55-77.81)\end{array}$ & $\begin{array}{c}58.19 \pm 7.19 \\
(46.66-69.53)\end{array}$ & $<0.001^{\#}$ & $\begin{array}{l}67.72 \pm 9.20 \\
(50-83.46)\end{array}$ & $\begin{array}{c}66.62 \pm 8.79 \\
(48.07-83.77)\end{array}$ & 0.067 & $<0.001^{\# \#}$ \\
\hline Excess body weight, $\mathrm{kg}$ & $\begin{array}{c}128.41 \pm 20.98 \\
(75.6-158.6)\end{array}$ & $\begin{array}{l}99.49 \pm 17.31 \\
(58.6-120.1)\end{array}$ & $<0.001^{\#}$ & $\begin{array}{c}126.21 \pm 21.39 \\
(69.9-155.1)\end{array}$ & $\begin{array}{l}122.91 \pm 18.59 \\
(63.0-149.9)\end{array}$ & 0.051 & $<0.001$ \\
\hline Actual weight loss, kg & \multicolumn{2}{|c|}{$28.92 \pm 10.08(17-52)$} & \multicolumn{3}{|c|}{$3.30 \pm 9.94(-15 \ldots+19)$} & & $<0.001^{\# \#}$ \\
\hline$\%$ EWL, \% & \multicolumn{2}{|c|}{$22.46 \pm 5.95(14.30-32.79)$} & \multicolumn{4}{|c|}{$1.87 \pm 9.25(-19.21 \ldots+23.17)$} & $<0.001^{\# \#}$ \\
\hline
\end{tabular}

Data are presented as mean \pm SD (min $-\max )$.

* Comparison between the main and control group after treatment.

\# In one or both groups the distribution of data differs from normal, the comparison was made using the Wilcoxon signed ranks test;

\#\# in one or both groups the distribution of data differs from normal, the comparison was made using the Wilcoxon-Mann-Whitney test. 
follow-up period for all patients in the first stage of treatment and 12 months - in the second stage. In this case, the time interval between the first and second stages was from 1 to 14 days.

After analysis of the anthropometric data of patients in both groups, it was noted that the mean BMI was 68.08 (95\% confidence interval (CI) $66.45-69.71) \mathrm{kg} / \mathrm{m}^{2}$. The mean weight of the patients was 191.63 (95\% CI 186.75-196.51) kg. The fact that the vast majority of them were of working age emphasizes the medical and social significance of the problem. A co-morbidity was frequently diagnosed, in particular, hypertension was observed in $88(90.7 \%)$ patients, coronary heart disease - in 61 (62.9\%), type 2 diabetes - in 70 (72.2\%) patients. The surgical and anaesthetic risk was graded as ASA PS 3.27 (95\% CI 3.18-3.36). All patients with severe and life-threatening systemic diseases or systemic pathology were assigned to ASA PS III and IV.

The endoluminal therapy included the application of an intragastric balloon (IGB), namely Orbera $^{\mathrm{TM}}$ Intragastric Balloon System produced by Apollo Endosurgery, Inc [6]. Prior to the IGB placement, esophagogastroduodenoscopy was performed to exclude any oesophageal, gastric or duodenal pathology. The patients received general anaesthesia with endotracheal intubation. The bariatric team included a bariatric surgeon, an anaesthesiologist and an endoscopist.

Under direct endoscopic visualization, the Placement Catheter Assembly containing the intragastric balloon was introduced perorally and then inserted down the oesophagus into the stomach. When it was confirmed that the balloon was below the lower oesophageal sphincter, the guidewire was removed. The Luer-Lock connector on the fill tube was connected to the filling system valve. Keeping the filling system valve open, a $50 \mathrm{cc}$ syringe was used to fill the balloon to $700 \mathrm{cc}$. To seal the balloon valve, a syringe was connected to the fill tube and a gentle suction was produced on the placement catheter by withdrawing the plunger of the syringe. The valve was sealed with the vacuum created. The fill tube was pulled until it was out of the self-sealing valve and removed along with the sheath through the mouth. Control gastroscopy was performed to check the location of the balloon in the stomach cavity as well as visually inspect the balloon for leakage. Additionally, ultrasound monitoring was carried out to observe the position of the balloon in the stomach.

The intragastric balloon was removed 6 months after the placement. The preparation of patients for esophagogastroduodenoscopy included administration of the endotracheal anaesthesia. Esophagogastroduodenoscopy was conducted to get a clear view of the balloon shell. A puncture needle produced by Prince medical was inserted down the working channel of the gastroscope. The needle was used to puncture the balloon and push the distal end of suction tubing through the balloon shell. The needle was removed from the tubing sleeve and suction was applied to the tube until all fluid was evacuated from the balloon. After evacuation of the maximum volume of fluid, the suction tubing was removed from the balloon and out of the working channel of the gastroscope. Under endoscopic visualization, a 2-prolonged wire grasper produced by Prince medical was inserted through the working channel of the gastroscope to remove the balloon. The 2-prolonged wire grasper helped firmly grasp the deflated balloon and extract it with minimal risk of injury to the stomach wall and oesophagus. The procedure was completed with the inspection of the duodenum, stomach, and oesophagus [2, 6].

Data were analysed with the statistical package IBM SPSS Statistics Base (version 22). All results were considered statistically significant at a value of $p<0.05$. Quantitative data are presented as mean \pm standard deviation (SD), unless otherwise stated. The normality of the data distribution was checked using the chi-square test $(p>0.05)$. The comparison was performed using the Wilcoxon sign rank criterion for related samples and the Wilcoxon-Mann-Whitney criterion for unrelated samples. Quantitative assessment of the clinical effect was performed by calculating the relative risk (RR) and its $95 \%$ CI.

\section{Results and discussion}

Before the first stage of treatment, a comparative analysis of body weight and other anthropometric variables was performed in the main and control groups (see Table 1). The findings did not reveal any statistically significant difference $(p>0.05)$ between the main and control groups before treatment.

The outcomes of the first stage of treatment showed that the patients, who underwent the IGB placement, had statistically significantly $(\mathrm{p}<0.001)$ higher mean \%EWL than the patients who received conservative therapy (see Table 1).

Six months after the IGB placement there was observed a statistically significant $(p<0.001)$ decrease in the mean systolic blood pressure (SBP) and the mean diastolic blood pressure (DBP) from 170.48 (95\% CI $166.90-174.07) \mathrm{mm} \mathrm{Hg}$ to $150.30(95 \%$ CI $147.47-153.13) \mathrm{mm} \mathrm{Hg}$ and from 104.88 (95\% CI 102.97-106.79) $\mathrm{mm} \mathrm{Hg}$ to 87.93 (95\% CI $86.42-89.45) \mathrm{mm} \mathrm{Hg}$, respectively. Ejection fraction (EF) increased from 
46.69 (95\% CI $45.36-48.02) \%$ to 49.55 (95\% CI 48.58-50.52)\% $(\mathrm{p}<0.001)$.

The study of the external respiration function parameters revealed the prevalence of the restrictive spirometric pattern in patients with morbid obesity. Six months after the IGB placement, the patients of the main group exhibited the unidirectional dynamics of mean values of vital capacity (VC), forced vital capacity (FVC), forced expiratory volume in one second (FEV1), peak expiratory flow rate (PEFR), maximum expiratory flow at $25 \% \mathrm{VC}$ (MEF25), maximum expiratory flow at $50 \% \mathrm{VC}$ (MEF50), maximum expiratory flow at $75 \%$ VC (MEF75), in the direction of their growth, which was interpreted as statistically significant. Notably, our study established the growth of FVC from 60.87 (95\% CI 59.56-62.18) \% to $73.25(95 \%$ CI $71.84-74.66) \%(\mathrm{p}<0.001)$.

Type 2 diabetes mellitus (DM) was diagnosed in the vast majority of patients in both groups. Thus, the glycosylated haemoglobin (HbA1c) test confirmed DM in $46(76.7 \%)$ patients in the main group and $24(64.9 \%)$ patients in the control group. $13(21.7 \%)$ patients of the main group and $11(29.7 \%)$ patients of the control group had an increased risk of developing type $2 \mathrm{DM}$ according to the ADA criteria (2018).

In patients of the main group, who underwent the IGB placement, the level of fasting plasma glucose and the level of glycosylated haemoglobin (HbA1c) decreased from 8.90 (95\% CI 8.43-9.36) $\mathrm{mmol} / \mathrm{L}$ to $7.86(95 \% \mathrm{CI} 7.43-8.29) \mathrm{mmol} / \mathrm{L}$ and from 7.38 (95\% CI 7.09-7.67) to 6.71 (95\% CI 6.44-6.97) respectively, in both cases $\mathrm{p}<0.001$. In the control group, the dynamics of these values did not reach the degree of statistical significance. It indicates the insufficient impact of conservative therapy. After the first stage of treatment that lasted 6 months, the level of fasting plasma glucose and the level of glycosylated haemoglobin in the main group were statistically significantly lower than in the control group $(p=0.028$ and $p=0.025$, respectively $)$.

Before treatment, all patients of both groups were assigned to ASA PS III-IV, in accordance with the inclusion criteria of this study. An overview of the first stage of treatment in terms of surgical and anaesthetic risk in the main and control groups suggests that the patients, who underwent the IGB placement, had statistically significantly $(\mathrm{p}<0.001)$ lower risk than the patients who received conservative therapy. In this case, the average ASA PS score in the main group decreased from $3.28(95 \% \mathrm{CI}$ $3.17-3.40)$ to 2.15 (95\% CI $2.06-2.24 ; \mathrm{p}<0.001)$, in the control group - from 3.24 (95\% CI3.10-3.39) to 3.14 (95\% CI 2.96-3.31; p >0.05) (Table 2).
The IGB placement for a term of 6 months reduces the initially high ASA PS score. It is essential for the first stage of treatment of patients with super-obesity and their preparation for bariatric surgery [1].

By \%EWL, an indicator of the effectiveness of treatment, the patients in the main and control groups were assessed as \%EWL $<20 \%$ or $\% \mathrm{EWL}$ $\geq 20 \%$. It has been established that the IGB placement results in a 3 times $(p<0.001)$ reduction of the risk of failure to achieve \%EWL $\geq 20$ in comparison with the conservative treatment methods, $\mathrm{RR}=0.33$ (95\% CI $0.22-0.47)$.

The IGB placement and removal were uneventful and without any complications. Short-term mild nausea was observed in 17 (28.33\%) patients and temporary discomfort in the epigastric region was seen in $22(36.66 \%)$ patients.

All patients of the main group, who underwent a 6-month treatment that involved the IGB placement as the preparation for bariatric surgery, were qualified for the second stage of treatment that included surgery, the mean \%EWL was 22.46 (95\% CI $20.93-24.0) \%$. Only $1(2.7 \%)$ patient in the control group met the criteria for bariatric surgery. 51 (83.6\%) patients underwent Laparoscopic Roux-en-Y Gastric Bypass (LRYGB), 9 (14.8\%) patients - Laparoscopic Adjustable Gastric Banding (LAGB), 1 (1.6\%) patient - Laparoscopic Sleeve Gastrectomy (LSG). 12 months after surgery, the mean \%EWL was 55.27 (95\% CI 53.32-57.23).

The safety analysis of the surgical methods applied in the treatment of patients with morbid obesity was also conducted. Thus, no complications were observed during the intraoperative period. Among general surgical postoperative complications, purulent wound infection was detected in $2(3.3 \%)$ patients with super-obesity. No specific postoperative complications were noted. There was no postoperative mortality among patients.

\section{Table 2. Distribution of patients by level of surgical and anaesthetic risk according to ASA PS in patients with super-obesity in the first stage of treatment}

\begin{tabular}{|c|c|c|c|c|}
\hline \multirow{2}{*}{$\begin{array}{l}\text { ASA } \\
\text { PS, } \\
\text { class }\end{array}$} & \multicolumn{2}{|c|}{ Main group $(n=60)$} & \multicolumn{2}{|c|}{ Control group $(n=37)$} \\
\hline & $\begin{array}{c}\text { Before } \\
\text { treatment }\end{array}$ & $\begin{array}{c}\text { After } \\
\text { treatment }\end{array}$ & $\begin{array}{c}\text { Before } \\
\text { treatment }\end{array}$ & $\begin{array}{c}\text { After } \\
\text { treatment }\end{array}$ \\
\hline I & 0 & 0 & 0 & 0 \\
\hline II & 0 & $51(85.0 \%)$ & 0 & $3(8.11 \%)$ \\
\hline III & $43(71.67 \%)$ & $9(15.0 \%)$ & $28(75.68 \%)$ & $26(70.27 \%)$ \\
\hline IV & $17(28.33 \%)$ & 0 & $9(24.32 \%)$ & $8(21.62 \%)$ \\
\hline
\end{tabular}


The debatable question is whether there are enough endoluminal methods for the treatment of these patients with MO. Thus, according to a study by L. Angrisani (2006), after removal of IGB $49.4 \%$ of patients with a baseline BMI of $54.4 \pm 8.1 \mathrm{~kg} / \mathrm{m}^{2}$, who were scheduled for further bariatric interventions, abandoned the latter. IGB was used as an independent method of treatment. However, it is important to note that their body weight returned to baseline after 12 months [16]. One of the reasons for insufficient weight loss or re-gain is non-compliance with the patient's appointments after bariatric interventions of the prescribed diet, excess caloric intake and sedentary lifestyle.

According to the WGO Global Guideline Obesity (2011), the use of IGB can help to form a certain stereotype of eating behaviour [17]. It has been shown that the use of IGB alone in patients with a BMI $\geq 40 \mathrm{~kg} / \mathrm{m}^{2}$ is ineffective because after removal of the balloon, patients either completely lost weight or lost weight [3]. This may be thought to be due in particular to «balloon cheating».

Thus, endoluminal procedures, especially the establishment of IGB, play an important role in the treatment of obese patients, but their use cannot be considered as the only and radical method of bariatric intervention in obese patients, especially morbid [2].

\section{Conclusions}

The presence of surgical and anesthetic risk graded as ASA PS III-IV in patients with super-obesity and the mean BMI of 68.08 (95\% CI 66.45-69.71) $\mathrm{kg} / \mathrm{m}^{2}$ complicated by pathologies of the cardiovascular system, impaired external respiration and poor carbohydrate metabolism necessitates the application of two-stage treatment involving the preparation of patients for bariatric surgery in the first stage.

The intragastric balloon placement for a term of 6 months ensures efficient preparation of super obese patients for bariatric surgery as it contributes to surgical and anesthetic risk reduction from 3.28 (95\% CI $3.17-3.40)$ to 2.15 (95\% CI 2.06-2.24; $\mathrm{p}<0.001)$, a decrease in BMI from $68.3(95 \%$ CI $66.39-70.20)$ to 58.19 (95\% CI $56.33-60.04) \mathrm{kg} / \mathrm{m}^{2}(\mathrm{p}<0.001)$, and the improved function of the cardiovascular and respiratory systems as well as better carbohydrate metabolism.

\section{DECLARATION OF INTERESTS}

The authors declare no conflicts of interest.

Funding. The work is a fragment of the planned research work of the Department of General Surgery No2 of Bohomolets National Medical University «Implementation of minimally invasive surgical techniques in the treatment of pathologies of the abdominal cavity, anterior abdominal wall, morbid obesity by fast-track technique» (State registration number $0118 \mathrm{U} 000147$ ).

\section{AUTHOR CONTRIBUTIONS}

O. Y. Ioffe: work concept and design, critical review, final approval of the article; M. S. Kryvopustov: data collection and analysis, statistical analysis, writing the article; O. P. Stetsenko, T.V. Tarasiuk, and Y.P. Tsiura: data collection and analysis, critical review.

\section{REFERENCES}

1. Ioffe OY, Kryvopustov MS, Tsiura YP. Substantiation of expediency of a two-staged surgical treatment of morbid obesity. Klinicheskaia Khirurgiia. 2018 Aug 30;85(8):49-2. https://hirurgiya. com.ua/index.php/journal/article/view/491.

2. Ioffe OY, Tsiura YP, Stetsenko OP, Tarasiuk TV, Kryvopustov MS, Molnar IM. Preoperative preparation opportunities for radical surgery in patients with morbid obesity. Surgery of Ukraine. 2014;(2):38-42.

3. Mitchenko OI, Lavrik AS, Shkroba AO, Romanov VY. Effect of medical and surgical treatment of obesity on cardiovascular risk in patients with arterial hypertension and morbid obesity. Ukrainian Journal of Cardiology. 2014;(4):17-25.

4. DeMaria EJ, Murr M, Byrne TK, et al. Validation of the obesity surgery mortality risk score in a multicenter study proves it stratifies mortality risk in patients undergoing gastric bypass for morbid obesity. Ann Surg. 2007 Oct;246(4):578-82.

5. DeMaria EJ, Portenier D, Wolfe L. Obesity surgery mortality risk score: proposal for a clinically useful score to predict mortality risk in patients undergoing gastric bypass. Surg Obes Relat Dis 2007 Mar-Apr;3(2):134-40.

6. Ioffe OYu, Kryvopustov MS, Dibrova YA, Tsiura YP. Type 2 diabetes mellitus remission and its prediction after two-stage surgical treatment of patients with morbid obesity. Wiad Lek. 2019;72(5):739-43.

7. Logue J, Thompson L, Romanes F, Wilson DC, Thompson J, Sattar N. Management of obesity: summary of SIGN guideline. BMJ. 2010 Feb 24;340:c154.

8. Mechanick JI, Youdim A, Jones DB, et al. Clinical practice guidelines for the perioperative nutritional, metabolic, and nonsurgical support of the bariatric surgery patient -2013 update: cosponsored by American Association of Clinical Endocrinologists, the Obesity Society, and American Society for Metabolic \& Bariatric Surgery. Endocr Pract. 2013 Mar-Apr;19(2):337-72.

9. Pineda E, Sanchez-Romero L, Brown M, et al. Achieving the 2025 WHO global health body-mass index targets: a modelling study on progress of the 53 countries in the WHO European region. The Lancet. 2016;388:590.

10. Rooney KD, Werrett GC. Obesity \& Anaesthesia [Internet]. [cited 2018 May 20]. Available from: http://www.anaesthesiauk.com/ documents/ obesity.pdf

11. Sapala JA, Wood MH, Schuhknecht MP, Sapala MA. Fatal pulmonary embolism after bariatric operations for morbid obesity: a 24-year retrospective analysis. Obes Surg. 2003 Dec;13(6):819-25.

12. Yoshizawa T, Ishikawa K, Nagasawa $H$, et al. A fatal case of supersuper obesity $(\mathrm{BMI}>80)$ in a patient with a necrotic soft tissue infection. Intern Med. 2018 May 15;57(10):1479-81.

13. Sallet JA, Marchesini JB, Paiva DS, et al. Brazilian multicenter study of the intragastric balloon. Obes Surg. 2004 Aug; 14(7):991-8.

14. Busetto L, Segato G, De Luca M, et al. Preoperative weight loss by intragastric balloon in super-obese patients treated with laparoscopic gastric banding: a case-control study. Obes Surg. 2004 May;14(5):671-6.

15. Dumonceau JM. Evidence-based review of the Bioenterics intragastric balloon for weight loss. Obes Surg. 2008 Dec;18(12):1611-7.

16. Angrisani L, Lorenzo M, Borrelli V, Giuffre M, Fonderico C, Capece $\mathrm{G}$. Is bariatric surgery necessary after intragastric balloon treatment? Obes Surg. 2006 Sep;16(9):1135-7.

17. Mathus-Vliegen L, Toouli J, Fried M, et al. Obesity: WGO Global Guideline [Internet]. 2011 [cited 2018 May 20]. Available from: http://www.worldgastroenterology.org/UserFiles/file/ guidelines/obesity-english-2011.pdf. 


\section{Роль ендолюмінальних втручань у підготовці пацієнтів високого ризику із суперожирінням до баріатричної операції}

\section{О. Ю. Іоффе, М. С. Кривопустов, О. П. Стеценко, Т. В. Тарасюк, Ю. П. Цюра}

Національний медичний університет імені О. О. Богомольця, Київ

Ожиріння призводить до підвищення рівня захворюваності, інвалідності та смертності, а також впливає на якість життя. 3 огляду на відомі ризики для здоров'я пацієнта, Міжнародна федерація хірургії ожиріння та метаболічних розладів (IFSO) приділяє особливу увагу проблемі морбідного ожиріння (індекс маси тіла $\geq 40$ кг $/ \mathrm{M}^{2}$ ) з акцентом на суперожирінні (індекс маси тіла $\geq 50$ кг $/ \mathrm{m}^{2}$ ).

Мета - вивчити роль ендолюмінальних втручань у підготовці пацієнтів із суперожирінням 3 високим ризиком хірургічних та анестезійних ускладнень до баріатричної хірургії.

Матеріали та методи. У період з 2011 до 2018 р. 97 пацієнтів із патологічним ожирінням та високим ризиком хірургічних і анестезіологічних ускладнень (ASA PS III - IV) пройшли курс лікування на клінічній базі кафедри загальної хірургії № 2 Національного медичного університету імені О. О. Богомольця. Лікування проводили в два етапи. В основній групі $(\mathrm{n}=60)$ перший етап лікування передбачав внутрішньошлункову установку балона на термін 6 міс. Контрольна група $(n=37)$ отримувала 6-місячну консервативну терапію. Другим етапом пацієнтам обох груп виконано оперативне втручання 3 метою лікування морбідного ожиріння.

Результати. Результати першого етапу лікування показали, що у пацієнтів, яким проведено внутрішньошлункову установку балона, був статистично значущо $(p<0,001)$ вищий середній відсоток втрати надлишкової маси тіла, ніж у пацієнтів, які отримували консервативну терапію. В основній групі середній бал за ASA PS (індикатор анестезіологічного та хірургічного ризику) знизився з 3,28 (95\% довірчий інтервал (ДІ) 3,17-3,40) до 2,15 (95\% ДІ 2,06-2,24; p <0,001), а у контрольній групі - 3 3,24 (95\% ДІ 3,10-3,39) до 3,14 (95\% ДІ 2,96-3,31; $>$ >0,05).

Висновки. Результати дослідження свідчать, що внутрішньошлункова установка балона на термін 6 міс знижує ризики хірургічного втручання і анестезії, поліпшує функції серцево-судинної та дихальної систем, а також прискорює вуглеводний обмін, тому цей підхід можна запропонувати для підготовки пацієнтів із суперожирінням з високим ризиком хірургічних ускладнень і ускладнень, пов'язаних з анестезією, до баріатричної хірургії.

Ключові слова: морбідне ожиріння, баріатрична хірургія, цукровий діабет 2 типу.

I Ioffe OY, Kryvopustov MS, Stetsenko OP, Tarasiuk TV, Tsiura YP. The role of endoluminal interventions in the preparation of high-risk patients with super-obesity for bariatric surgery. General Surgery (Ukraine). 2021:1;18-23. http://doi.org/10.30978/GS-2021-1-18.
} 